Supporting Information for

\title{
Control of Molecular Orientation in Organic Semiconductors Using Weak Iodine-Iodine Interactions
}

Amane Matsunaga, ${ }^{\ddagger}$ Yuta Ogawa, Daisuke Kumaki, ${ }^{\S}$ Shizuo Tokito, ${ }^{\S}$ and Hiroshi Katagiri ${ }^{\star *}$

${ }^{*}$ Graduate School of Science and Engineering, Yamagata University, 4-3-16 Jonan, Yonezawa, Yamagata 992-8510, Japan

${ }^{\S}$ Graduate School of Organic Materials Science, Yamagata University, 4-3-16 Jonan, Yonezawa, Yamagata, 992-8510, Japan

\section{Contents}

1. General characterization

2. Synthesis

3. ${ }^{1} \mathrm{H}$ and ${ }^{13} \mathrm{C}$ NMR and FD-HRMS spectra for I-ATT

4. Thermogravimetric analysis (TGA)

5. X-ray crystallographic data and structure refinement for I-ATT

6. Device fabrication and evaluation

7. Computational methods

8. References 


\section{General characterization}

Melting points $(\mathrm{mp})$ were determined with a SANSYO SMP-300CT apparatus. Nuclear magnetic resonance spectra (NMR) were obtained using a JEOL JNM-ECX spectrometer operating at $500 \mathrm{MHz}$ for ${ }^{1} \mathrm{H}$ or $125 \mathrm{MHz}$ for ${ }^{13} \mathrm{C}$. Field-desorption high-resolution mass spectrometry (FD-HRMS) was conducted using a JEOL JMST100GCV instrument. Infrared (IR) spectroscopy was performed using a Jasco FT/IR-460 plus instrument. Ultraviolet-visible (UV-vis) spectra were acquired on a JASCO V-650 spectrophotometer. Cyclic voltammogram traces were recorded using a BAS 612E electrochemical system with a Pt working electrode, a Pt counter electrode, an $\mathrm{Ag} / \mathrm{AgNO}_{3}$ reference electrode, and the ferrocene/ferrocenium $\left(\mathrm{Fc} / \mathrm{Fc}^{+}\right)$external reference. Photoemission yield spectroscopy was performed on a RIKEN KEIKI AC-3 instrument. Thin-film X-ray diffraction (XRD) patterns were recorded on a Rigaku SmartLab system. Thermogravimetric analysis (TGA) was performed on a TA Instruments SDT Q600 analyzer. Atomic force microscopy (AFM) images were recorded using a Bruker Dimension Icon microscope.

\section{Synthesis}

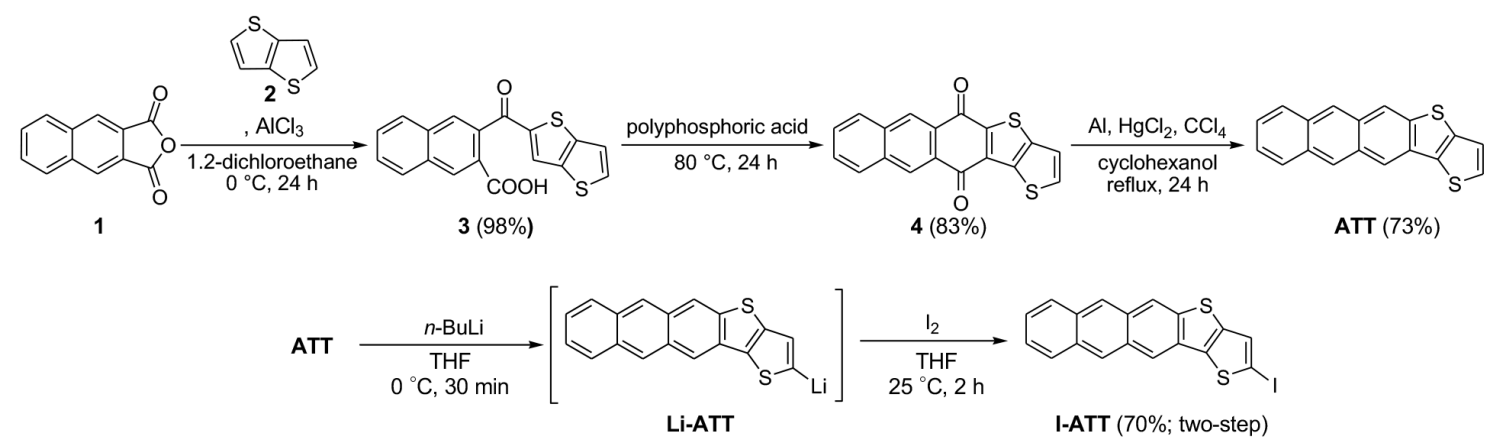

Scheme S1. Synthesis route to compound 3, compound 4, anthra[2,3-b]thieno[2,3- $d]$ thiophene (ATT) and 2-iodonthra[2,3-b] thieno[2,3-d] thiophene (I-ATT).

ATT was synthesized as follows according to ref 1 , and I-ATT was synthesized by selective iodination of ATT.

\section{3-\{Thieno[3,2-b]thiophen-2-yl\}-2-naphthoic Acid (3):}

Aluminum chloride $(4.20 \mathrm{~g}, 31.5 \mathrm{mmol})$ was added to a solution of 2,3-naphthalenedicarboxylic anhydride (compound 1) (2.83 g, $14.3 \mathrm{mmol})$ in 1,2-dichloroethane (60 mL). After $30 \mathrm{~min}$ of stirring at $0{ }^{\circ} \mathrm{C}$, a solution of thieno[3,2-b]thiophene (compound 2) (2.00 g, $\left.14.3 \mathrm{mmol}\right)$ in 1,2-dichloroethane $(40 \mathrm{~mL})$ was added dropwise over $1 \mathrm{~h}$. The resultant mixture was stirred for $24 \mathrm{~h}$ at $0{ }^{\circ} \mathrm{C}$ under a nitrogen atmosphere and then treated with $10 \%$ aqueous hydrochloric acid $(30 \mathrm{~mL})$. The resultant precipitate was collected by filtration, and the residue was washed with water to obtain compound 3 
(4.74 g, 98\%). Colorless crystals; mp $244-246{ }^{\circ} \mathrm{C} ;{ }^{1} \mathrm{H}$ NMR $\left(500 \mathrm{MHz}\right.$, DMSO- $\left.d_{6}, 35{ }^{\circ} \mathrm{C}\right) \delta(\mathrm{ppm})$ $8.65(\mathrm{~s}, 1 \mathrm{H}), 8.23-8.21(\mathrm{~m}, 1 \mathrm{H}), 8.20(\mathrm{~s}, 1 \mathrm{H}), 8.13-8.11(\mathrm{~m}, 1 \mathrm{H}), 8.00(\mathrm{~d}, J=5.1 \mathrm{~Hz}, 1 \mathrm{H}), 7.79(\mathrm{~s}$, $1 \mathrm{H}), 7.77-7.71(\mathrm{~m}, 2 \mathrm{H}), 7.57(\mathrm{~d}, J=5.1 \mathrm{~Hz}, 1 \mathrm{H}) ;{ }^{13} \mathrm{C}$ NMR $\left(125 \mathrm{MHz}\right.$, DMSO- $\left.d_{6}, 35^{\circ} \mathrm{C}\right) \delta(\mathrm{ppm})$ $189.26,167.18,145.40,144.49,139.15,136.43,134.57,133.45,132.43,131.26,129.07,129.05$, 128.48, 9906 128.39, 128.21, 128.02, 127.86, 120.50; HRMS (FD $\left.{ }^{+}\right): m / z$ calcd. for $\mathrm{C}_{18} \mathrm{H}_{10} \mathrm{O}_{3} \mathrm{~S}_{2}\left[\mathrm{M}^{+}\right]$: 338.00714 , found 338.00676 .

\section{Anthra[2,3-b] thieno[2,3-d] thiophene-5,12-dione (4):}

A mixture of compound $3(4.00 \mathrm{~g}, 11.8 \mathrm{mmol})$ and polyphosphoric acid was heated at $80{ }^{\circ} \mathrm{C}$ for $24 \mathrm{~h}$. After the reaction mixture was cooled, it was poured into ice water $(1000 \mathrm{~mL})$, and the resultant precipitate was collected by filtration. The precipitate was extracted thrice with chloroform $(200 \mathrm{~mL})$ using an ultrasonic bath, and the solvent was removed under reduced pressure to give compound 4 $(2.80 \mathrm{~g}, 74 \%)$. Yellow powder; $\mathrm{mp}>300{ }^{\circ} \mathrm{C} ;{ }^{1} \mathrm{H}$ NMR $\left(500 \mathrm{MHz}\right.$, DMSO- $\left.d_{6}, 100{ }^{\circ} \mathrm{C}\right) \delta(\mathrm{ppm}) 8.80(\mathrm{~s}$, $2 \mathrm{H}), 8.34-8.32(\mathrm{~m}, 2 \mathrm{H}), 8.20(\mathrm{~d}, J=5.1 \mathrm{~Hz}, 1 \mathrm{H}), 7.82-7.79(\mathrm{~m}, 2 \mathrm{H}), 7.73(\mathrm{~d}, J=5.1 \mathrm{~Hz}, 1 \mathrm{H}) ;{ }^{13} \mathrm{C}$ NMR (125 MHz, DMSO- $\left.d_{6}, 100^{\circ} \mathrm{C}\right) \delta(\mathrm{ppm}) 177.35,177.33,147.26,143.71,136.05,135.96,135.42$, $133.98,133.95,129.65,129.65,129.46,129.38,129.30,128.83,128.63,128.37,120.04$; HRMS $\left(\mathrm{FD}^{+}\right): m / z$ calcd. for $\mathrm{C}_{18} \mathrm{H}_{8} \mathrm{O}_{2} \mathrm{~S}_{2}\left[\mathrm{M}^{+}\right]: 319.99657$, found 319.99723 .

\section{Anthra[2,3-b]thieno[2,3- $d]$ thiophene (ATT):}

Aluminum wire $(2.1 \mathrm{~g})$ was reacted in $50 \mathrm{~mL}$ of dry cyclohexanol containing mercuric chloride (40 $\mathrm{mg}$ ) and carbon tetrachloride $(2.2 \mathrm{~mL})$ under reflux heating by a heating gun. After the mixture was cooled at $25^{\circ} \mathrm{C}$, compound $4(2.80 \mathrm{~g}, 8.74 \mathrm{mmol})$ was added. The resultant mixture was stirred for 24 $\mathrm{h}$ at $160^{\circ} \mathrm{C}$ under nitrogen atmosphere and then treated with $13 \%$ aqueous hydrochloric acid $(120 \mathrm{~mL})$. The mixture was poured into methanol $(200 \mathrm{~mL})$, and the resultant precipitate was collected by filtration to give ATT $(1.86 \mathrm{~g}, 73 \%)$. Yellow powder, $\mathrm{mp}>300{ }^{\circ} \mathrm{C} ;{ }^{1} \mathrm{H} \mathrm{NMR}\left(500 \mathrm{MHz}, \mathrm{CDCl}_{3}, 35^{\circ} \mathrm{C}\right)$ $\delta(\mathrm{ppm}) 8.58(\mathrm{~s}, 1 \mathrm{H}), 8.49(\mathrm{~s}, 1 \mathrm{H}), 8.46(\mathrm{~s}, 2 \mathrm{H}), 8.04-8.00(\mathrm{~m}, 2 \mathrm{H}), 7.59(\mathrm{~d}, \mathrm{~J}=5.1 \mathrm{~Hz}, 1 \mathrm{H}), 7.47-$ $7.43(\mathrm{~m}, 2 \mathrm{H}), 7.31(\mathrm{~d}, J=5.1 \mathrm{~Hz}, 1 \mathrm{H}) ;{ }^{13} \mathrm{C} \mathrm{NMR}\left(125 \mathrm{MHz}, \mathrm{CDCl}_{3}, 35{ }^{\circ} \mathrm{C}\right) \delta(\mathrm{ppm}) 141.60,139.24$, 133.92, 132.07, 131.52, 131.49, 129.66, 129.53, 129.41, 128.18, 128.11, 126.33, 125.31, 125.26, 125.22, 122.01, 120.89, 118.51; HRMS $\left(\mathrm{FD}^{+}\right) \mathrm{m} / z$ calcd. for $\mathrm{C}_{18} \mathrm{H}_{10} \mathrm{~S}_{2}\left[\mathrm{M}^{+}\right]: 290.02239$, found 290.02224 . 


\section{2-iodoanthra[2,3-b] thieno[2,3- $d]$ thiophene (I-ATT):}

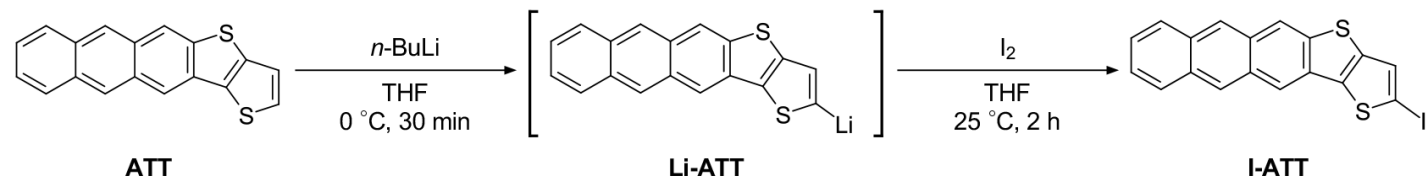

To a solution of anthra[2,3-b]thieno[2,3-d] thiophene ${ }^{1}$ (ATT) $(150 \mathrm{mg}, 0.52 \mathrm{mmol})$ in anhydrous THF $(100 \mathrm{~mL})$ was added $n$-butyllithium $(1.0 \mathrm{~mL}$ of a $1.6 \mathrm{M}$ hexane solution, $1.6 \mathrm{mmol})$ at $0{ }^{\circ} \mathrm{C}$ under a nitrogen atmosphere. The reaction mixture was stirred at $0{ }^{\circ} \mathrm{C}$ for $30 \mathrm{~min}$ before iodine ( $393 \mathrm{mg}, 1.6$ mmol) was added, and then the mixture was stirred at $25{ }^{\circ} \mathrm{C}$ for $2 \mathrm{~h}$. After, the reaction mixture was poured into $5 \mathrm{wt} \% \mathrm{Na}_{2} \mathrm{SO}_{3}$ aq. ( $\left.300 \mathrm{~mL}\right)$ for quenching and stirred for $1 \mathrm{~h}$. The resulting precipitate was filtered to give the crude product as an orange solid $(230 \mathrm{mg})$. The residue was purified by silica gel column chromatography (200-400 mesh silica gel, dichloromethane) to afford 2-iodoanthra[2,3$b]$ thieno[2,3- $d$ ] thiophene (I-ATT) (150 mg, 70\%). yellow powder; mp $227{ }^{\circ} \mathrm{C}$ (decomp.); ${ }^{1} \mathrm{H}$ NMR $\left(500 \mathrm{MHz}, \mathrm{CDCl}_{3}, 35^{\circ} \mathrm{C}\right) \delta(\mathrm{ppm}) 8.58(\mathrm{~s}, 1 \mathrm{H}), 8.48(\mathrm{~s}, 1 \mathrm{H}), 8.44(\mathrm{~s}, 1 \mathrm{H}), 8.40(\mathrm{~s}, 1 \mathrm{H}), 8.03-8.01(\mathrm{~m}$, 2H), 7.47-7.45 (m, 3H); ${ }^{13} \mathrm{C}$ NMR (125 MHz, DMSO- $\left.d_{6}, 80{ }^{\circ} \mathrm{C}\right) \delta(\mathrm{ppm}) 139.6,139.0,137.4,130.8$, 130.7, 130.3, 130.0, 128.8, 128.7, 127.6, 127.5, 125.9, 125.1, 125.0, 124.7, 121.9, 118.5, 79.9; IR $(\mathrm{KBr}): v=3048(\mathrm{Ar}-\mathrm{H}), 896(\mathrm{C}-\mathrm{C}) \mathrm{cm}^{-1}$; HRMS $\left(\mathrm{FD}^{+}\right): \mathrm{m} / z$ calcd. for $\mathrm{C}_{18} \mathrm{H}_{9} \mathrm{IS}_{2}\left[\mathrm{M}^{+}\right]: 415.91903$; found: 415.90961; elemental analysis calcd. (\%) for $\mathrm{C}_{18} \mathrm{H}_{9} \mathrm{IS}_{2}$ : C, 51.93; H, 2.18; Found C, 51.83; H, 2.25 . 


\section{3. ${ }^{1} \mathrm{H}$ and ${ }^{13} \mathrm{C}$ NMR and FD-HRMS spectra for I-ATT}

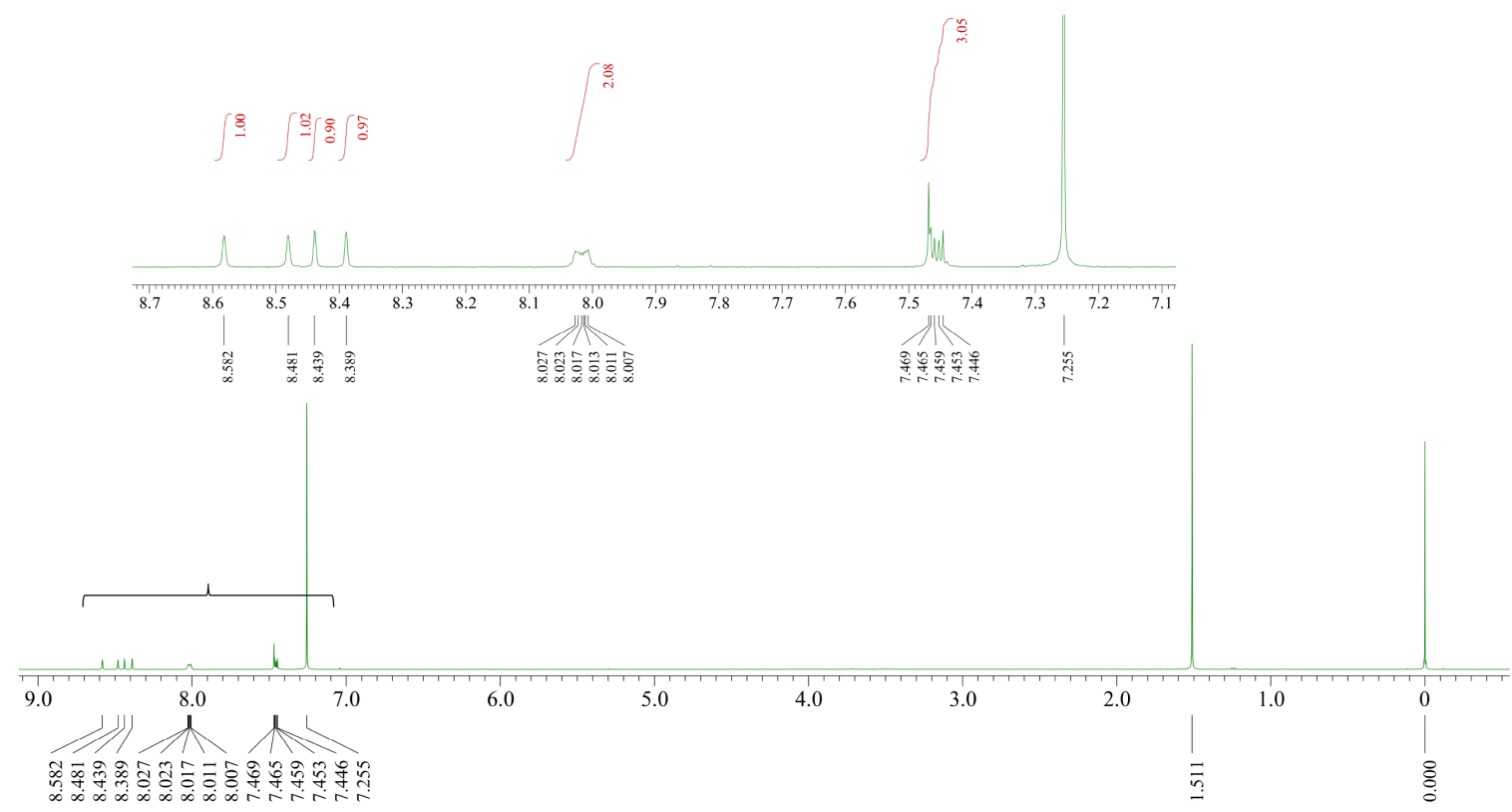

Figure S1. ${ }^{1} \mathrm{H}$ NMR of I-ATT $\left(500 \mathrm{MHz}, \mathrm{CDCl}_{3}, 35^{\circ} \mathrm{C}\right)$

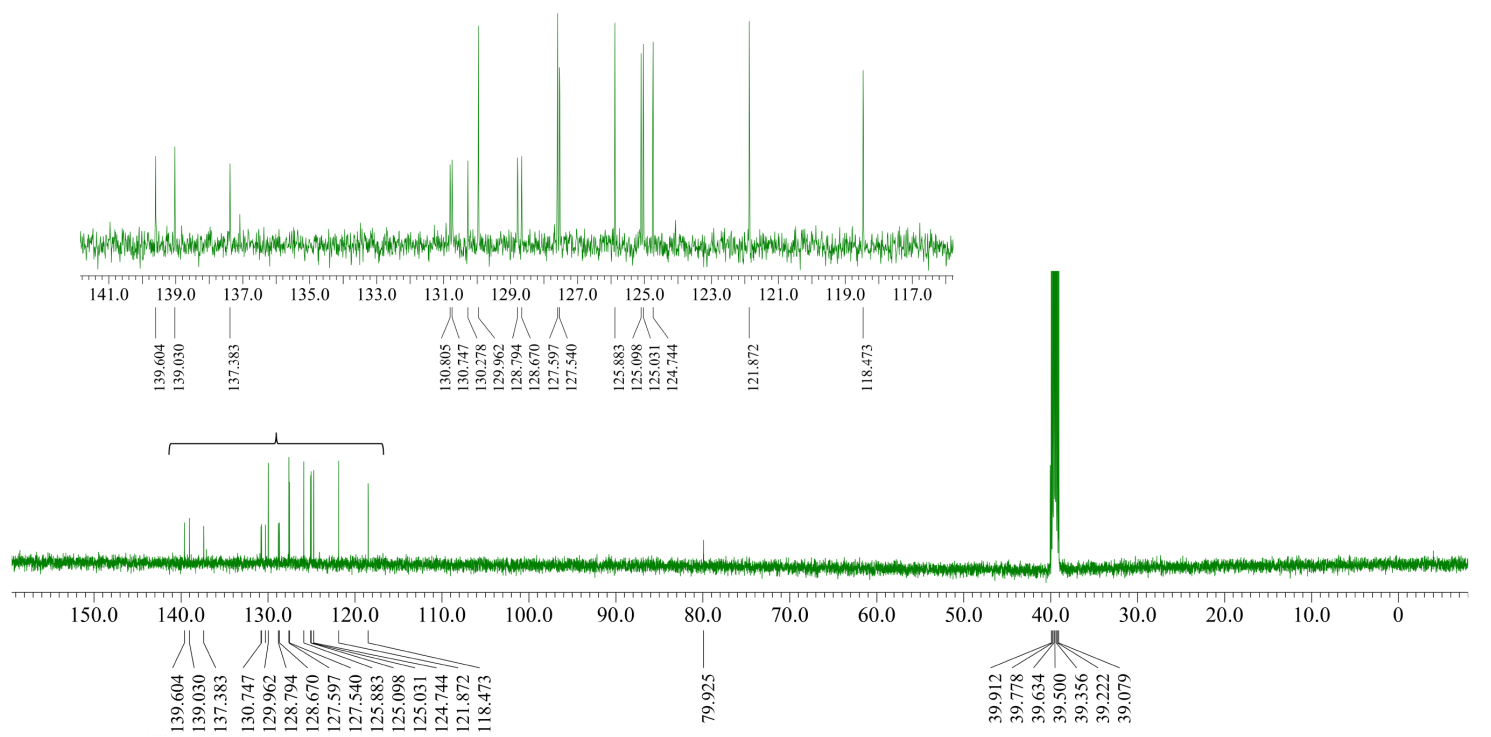

Figure S2. ${ }^{13} \mathrm{C}$ NMR of I-ATT $\left(500 \mathrm{MHz}\right.$, DMSO- $\left.d_{6}, 80{ }^{\circ} \mathrm{C}\right)$

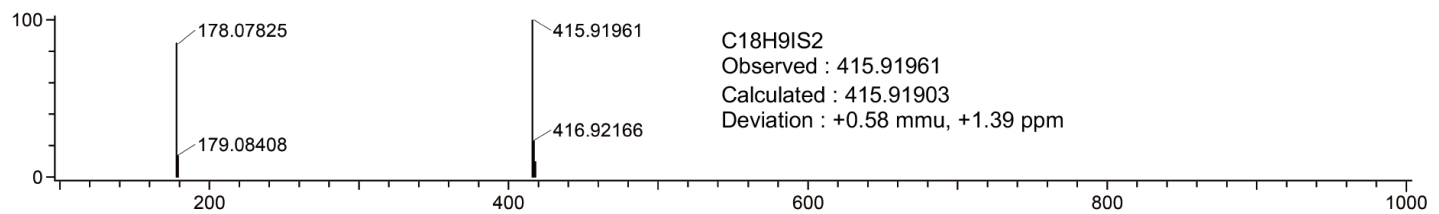

Figure S3. FD-HRMS spectrum of I-ATT with anthracene [calcd. for $\mathrm{C}_{14} \mathrm{H}_{10}\left(\mathrm{M}^{+}\right): m / z=178.07825$ ] as an internal standard. 


\section{TGA}

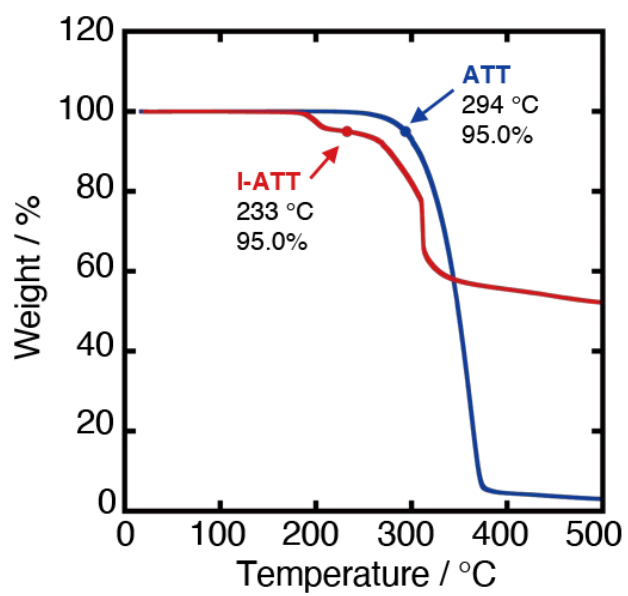

Figure S4. TGA traces for ATT (blue) and I-ATT (red). The heating rate was $10{ }^{\circ} \mathrm{C} \min ^{-1}$ under a $\mathrm{N}_{2}$ atmosphere.

\section{X-ray crystallographic data and structure refinement for I-ATT}

XRD data for I-ATT was collected on a Rigaku Saturn 724 charged-coupled-device (CCD) diffractometer using Mo-K $\alpha(\lambda=0.71075 \AA)$. Single crystals of I-ATT $\left(\mathrm{C}_{18} \mathrm{H}_{9} \mathrm{IS}_{2}, \mathrm{Mw}=416.29\right)$ suitable for X-ray analysis were recrystallized by tetralin. Data collection, cell refinements, and data reductions were conducted using the CrysAlisPro software. ${ }^{2}$ These structures were solved by direct methods using the SHELXT ${ }^{3}$ program and were refined by full-matrix least-squares methods on $F^{2}$ using SHELXL2014. ${ }^{4}$ All materials for publication were prepared using the Yadokari-XG 2009 software. ${ }^{5}$ All nonhydrogen atoms were refined anisotropically. The positions of all hydrogen atoms were calculated geometrically and refined using a riding model.

Table S1. Crystal data and structure refinement for I-ATT.

\begin{tabular}{cc}
\hline Compound & I-ATT \\
\hline Chemical formula & $\mathrm{C}_{18} \mathrm{H}_{9} \mathrm{~S}_{2} \mathrm{I}_{1}$ \\
Formula weight & 416.27 \\
Temperature $(\mathrm{K})$ & 93 \\
Radiation type & Mo $K \alpha$ \\
Wavelength $(\AA)$ & 0.71073 \\
Crystal system & Monoclinic \\
Space group & $P \mathrm{c}$ \\
$a(\AA)$ & $5.9937(10)$ \\
$b(\AA)$ & $31.533(5)$ \\
$c(\AA)$ & $7.4479(9)$
\end{tabular}


$\alpha\left(^{\circ}\right)$

$\beta\left(^{\circ}\right)$

$\gamma\left({ }^{\circ}\right)$

Volume $\left(\AA^{3}\right)$

$Z$

Density (calculated) $\left(\mathrm{g} \mathrm{cm}^{-3}\right)$

Absorption coefficient $\left(\mathrm{mm}^{-1}\right)$

$\mathrm{F}(000)$

Crystal size $\left(\mathrm{mm}^{3}\right)$

Theta range for data collection $\left({ }^{\circ}\right)$

Index ranges

Reflections collected

Independent reflections

Completeness (\%)

Absorption correction

Maximum and minimum transmission

Refinement method

Data/restraints/parameters

Goodness-of-fit on $F^{2}$

Final $R$ indices $[I>2 \sigma(I)]$

$\mathrm{R}$ indices (all data)

Largest diff. peak and hole $\left(\mathrm{e} \cdot \AA^{-3}\right)$
90

91.034(12)

90

1407.4(4)

4

1.965

2.560

808

$0.200 \times 0.100 \times 0.050$

5.855 to 24.407

$-6 \leq h \leq 6,-36 \leq k \leq 36,-8 \leq l \leq 8$

13489

$4528\left[R_{\text {int }}=0.1254\right]$

$98.3\left(\theta=24.407^{\circ}\right)$

Semi-empirical from equivalents

1.00000 and 0.50837

Full-matrix least-squares on $F^{2}$

4528 / 527 / 362

1.844

$R_{1}=0.1558, w R_{2}=0.4193$

$R_{1}=0.1633, w R_{2}=0.4314$

6.141 and -2.365

\section{Device fabrication and evaluation}

Top-contact bottom-gate organic field-effect transistors (OFETs) were constructed on heavily doped $n$-type silicon wafers covered with thermally grown silicon dioxide $(200 \mathrm{~nm})$, which were cleaned with piranha solution. Silicon dioxide acts as a gate dielectric layer, and the silicon wafer serves as the gate electrode. Polystyrene (molecular weight $(\mathrm{Mw}) 280,000$ ) was prepared by spin-coating from a $0.5 \mathrm{wt} \%$ solution in $m$-xylene at a rotational speed of $500 \mathrm{rpm}$ for $5 \mathrm{~s}$ and then at $4000 \mathrm{rpm}$ for $60 \mathrm{~s}$, followed by annealing at $150^{\circ} \mathrm{C}$ for $1 \mathrm{~h}$ under nitrogen. Organic semiconductor layers (ca. $\sim 240 \mathrm{~nm}$ ) were formed by drop-casting a $0.5 \mathrm{wt} \%$ solution of I-ATT or ATT in tetralin at $100{ }^{\circ} \mathrm{C}$ followed by annealing at $150{ }^{\circ} \mathrm{C}$ for $1 \mathrm{~h}$. Topcontact gold source-drain electrodes $(50 \mathrm{~nm})$ were deposited on the organic semiconductor layers through a shadow mask with a length/width ratio $(L / W)$ of 100/1500 $\mu \mathrm{m}$. FET measurements were carried out at $25^{\circ} \mathrm{C}$ in air using a semiconductor parameter analyzer (4200-SCS, KEITHLEY). The mobilities $(\mu)$ were calculated in the saturation regime using the relationship $\mu_{\text {sat }}=\left(2 I_{\mathrm{D}} L\right) /\left[W C_{\mathrm{i}}\left(V_{\mathrm{G}}-V_{\mathrm{th}}\right)^{2}\right]$, where $I_{\mathrm{D}}$ is the source-drain saturation current, $C_{\mathrm{i}}$ is the capacitance of the insulating layer, $V_{\mathrm{G}}$ is the gate voltage, and $V_{\text {th }}$ 
is the threshold voltage. The latter was estimated from the intercept of the linear section of the plot of $V_{\mathrm{G}}$ vs $\left(I_{\mathrm{D}}\right)^{1 / 2}$.
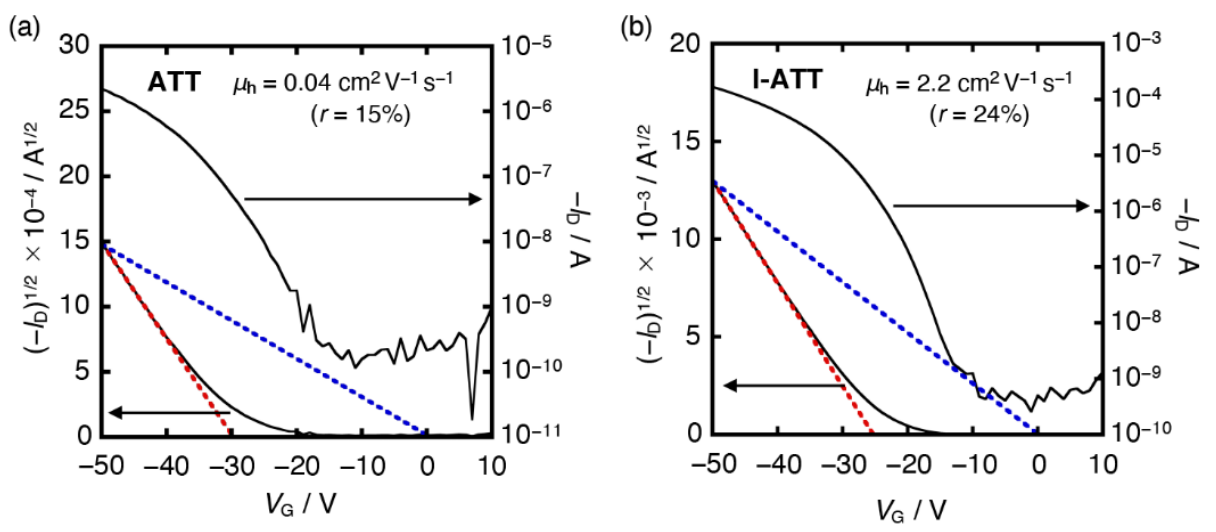

Figure S5. Transfer curve of the ATT(a) and I-ATT(b) devices. The blue and red dashed lines indicate slopes used in assessing the calculated mobility $\left(\mu_{\text {cal }}\right)$ and experimentally saturated mobility $\left(\mu_{\text {sat }}\right)$, respectively. The reliability factor $(r)$ is defined as the ratio of the maximum channel conductivity experimentally achieved in an OFET at the maximum $V_{\mathrm{G}}$ to the channel conductivity expected in an ideal functioning OFET.

$$
r=\frac{\left(\frac{\sqrt{\left|I_{\mathrm{D}}\right|^{\text {max }}}-\left|I_{\mathrm{D}}^{0}\right|}{\left|V_{\mathrm{G}}\right|^{\text {max }}}\right)^{2}}{\left(\frac{\partial \sqrt{\left|I_{\mathrm{D}}\right|}}{\partial V_{\mathrm{G}}}\right)^{2}}
$$
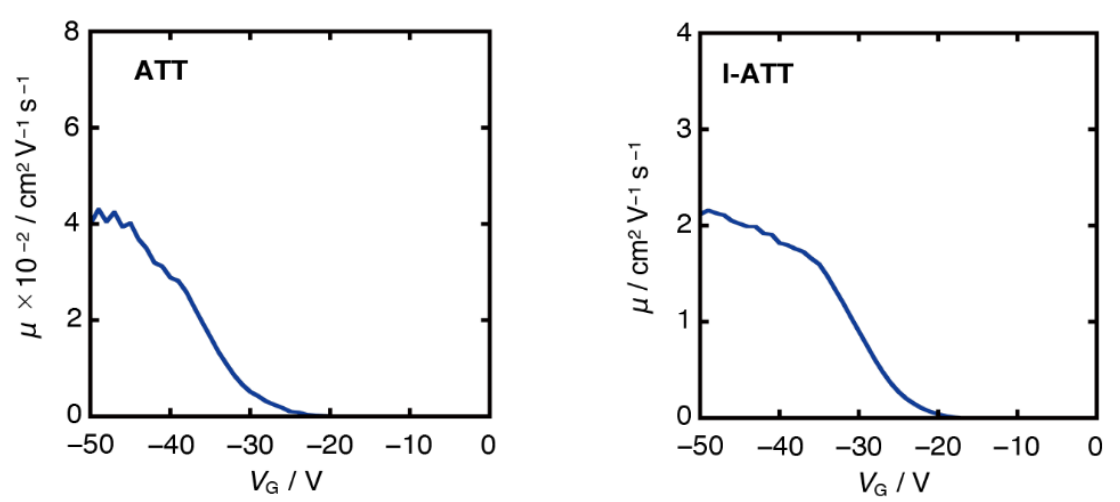

Figure S6. Mobility as a function of $V_{\mathrm{G}}$ in OFET devices with ATT (left) I-ATT (right) thin films. 

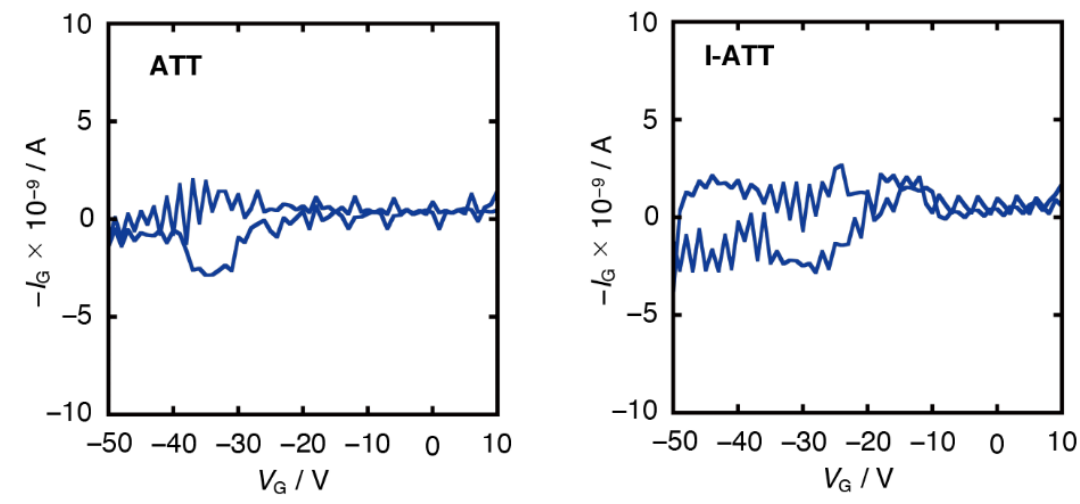

Figure S7. Current leakage characteristics of ATT (left) and I-ATT (right) thin films.
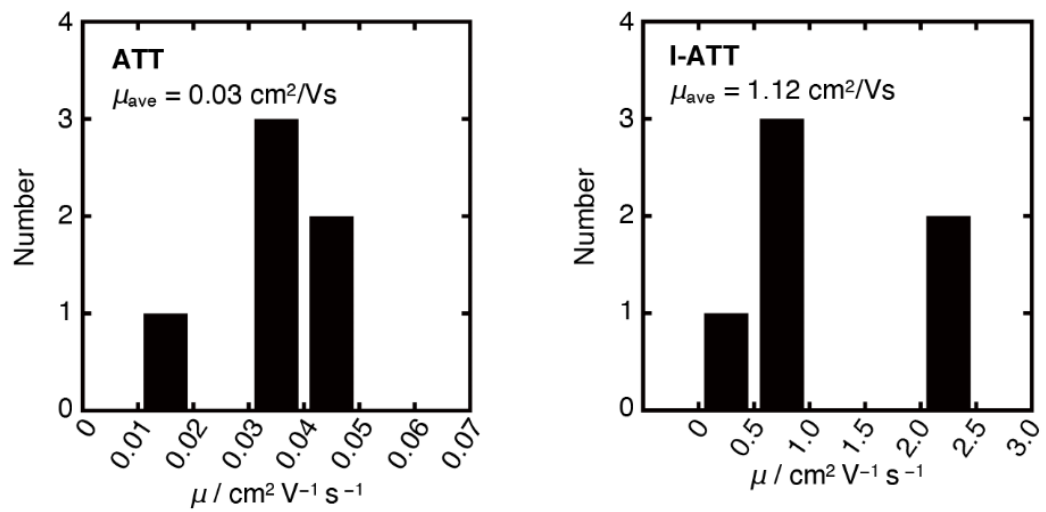

Figure S8. Histograms of the mobility distributions obtained from six OFET devices with ATT (left) and I-ATT (right) thin films.

\section{Computational methods}

The geometry optimizations of I-ATT and ATT were performed using the DFT/B3LYP method with the $6-31+\mathrm{G}(\mathrm{d}, \mathrm{p})$ basis set for $\mathrm{C}, \mathrm{H}$, and $\mathrm{S}$, and the LanL2DZ basis set for I under the Gaussian 09 program package. ${ }^{6}$ The transfer integrals were calculated at the M06-2X/TZ2P level using the ADF package. ${ }^{7}$ The molecular coordinates determined by single-crystal XRD were used without further geometric optimization in the transfer integral calculations. The reorganization energies $\left(\lambda_{+}\right)$were calculated by the DFT/B3LYP method with the $6-31+\mathrm{G}(\mathrm{d}, \mathrm{p})$ basis set for $\mathrm{C}, \mathrm{H}$, and $\mathrm{S}$, and the LanL2DZ basis set for I. The reorganization energy for hole transport $\lambda_{+}$is given by $\lambda_{1}+\lambda_{2}$, where $\lambda_{1}$ is the difference between the energies of the cation molecule in the neutral and cation geometries, and $\lambda_{2}$ is the difference between the energies of the neutral molecule in the neutral and cation geometries. 
(a)

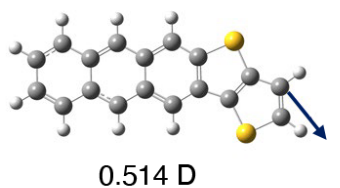

Front View

Side View
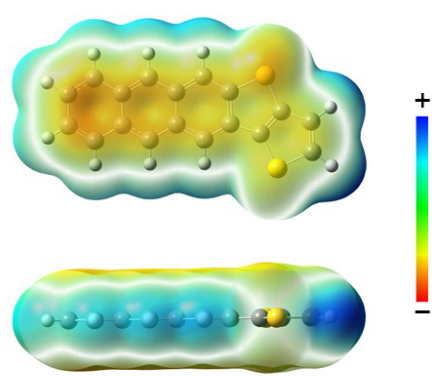

(b)
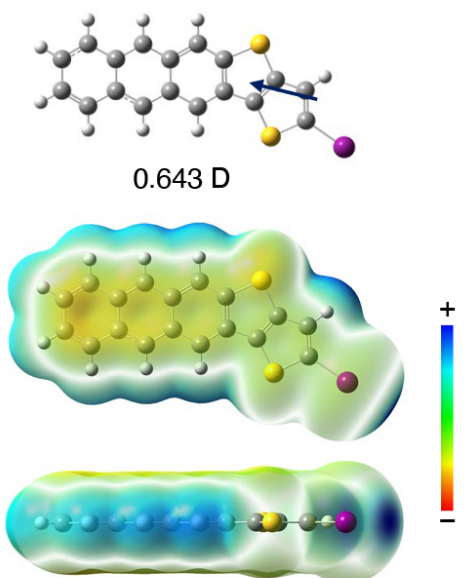

Figure S9. Optimized structures, dipole moments, and electrostatic potential maps of (a) ATT and (b) I-ATT.

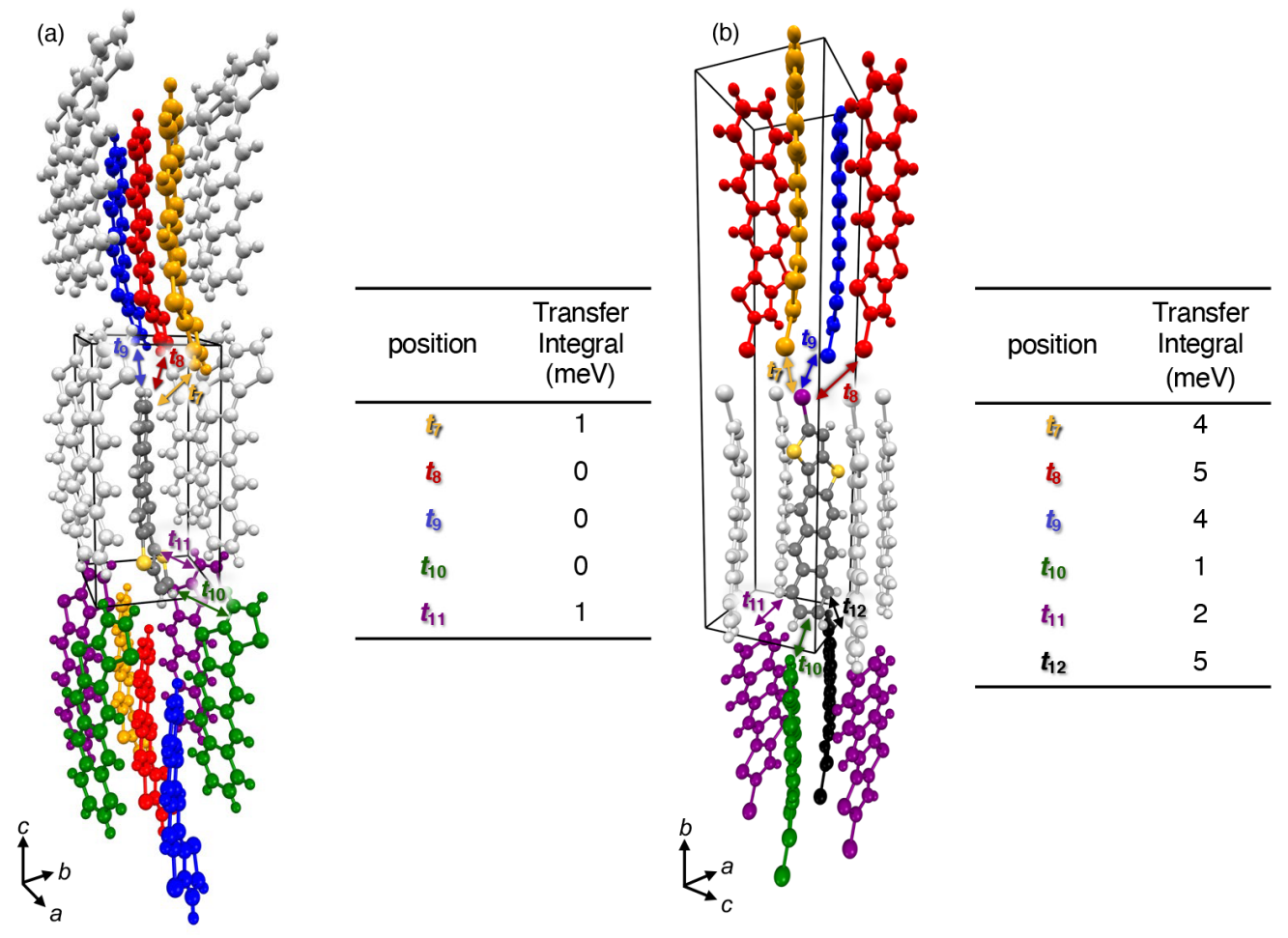

Figure S10. Transfer integrals for all molecular pairs in the end-to-end direction on (a) ATT and (b) I-ATT 
Table S2. Cartesian coordinates of the optimized geometry of ATT at B3LYP/6-31+G(d,p) level of theory $(E=-1488.37306813$, number of imaginary frequencies $=0)$.

\begin{tabular}{rrrr}
\hline Atom & $\mathrm{X}$ & $\mathrm{Y}$ & $\mathrm{Z}$ \\
\hline $\mathrm{C}$ & -10.281497 & -5.044752 & -0.970432 \\
$\mathrm{C}$ & -9.008869 & -4.819096 & -1.427544 \\
$\mathrm{C}$ & -8.152567 & -3.867405 & -0.784933 \\
$\mathrm{C}$ & -8.658759 & -3.144607 & 0.362135 \\
$\mathrm{C}$ & -9.993774 & -3.411488 & 0.805901 \\
$\mathrm{C}$ & -10.780915 & -4.331134 & 0.161910 \\
$\mathrm{C}$ & -6.849552 & -3.615500 & -1.228307 \\
$\mathrm{C}$ & -7.831472 & -2.211629 & 0.998856 \\
$\mathrm{C}$ & -6.523959 & -1.956255 & 0.556846 \\
$\mathrm{C}$ & -6.015380 & -2.679979 & -0.592589 \\
$\mathrm{C}$ & -4.689892 & -2.425229 & -1.045705 \\
$\mathrm{H}$ & -4.314449 & -2.970724 & -1.907519 \\
$\mathrm{C}$ & -3.892037 & -1.501047 & -0.403246 \\
$\mathrm{C}$ & -5.683610 & -1.003596 & 1.208992 \\
$\mathrm{H}$ & -6.469469 & -4.158995 & -2.090479 \\
$\mathrm{H}$ & -10.919110 & -5.769550 & -1.468141 \\
$\mathrm{H}$ & -8.627862 & -5.361524 & -2.289073 \\
$\mathrm{H}$ & -10.372985 & -2.868013 & 1.667573 \\
$\mathrm{H}$ & -11.791641 & -4.522772 & 0.510187 \\
$\mathrm{H}$ & -8.212317 & -1.668532 & 1.860957 \\
$\mathrm{H}$ & -6.067863 & -0.463265 & 2.069651 \\
$\mathrm{C}$ & -4.412974 & -0.785240 & 0.743669 \\
$\mathrm{~S}$ & -3.230847 & 0.357247 & 1.425644 \\
$\mathrm{C}$ & -2.054409 & -0.112222 & 0.197204 \\
$\mathrm{C}$ & -2.541507 & -1.075380 & -0.668176 \\
$\mathrm{~S}$ & -1.345457 & -1.502790 & -1.857905 \\
$\mathrm{C}$ & -0.718699 & 0.297200 & -0.078920 \\
\hline & -0.211472 & -0.372283 & -1.163007 \\
$\mathrm{C}$ & -0.163630 & 1.037933 & 0.483620 \\
\hline & 0.771428 & -0.270222 & -1.602628 \\
\hline & & &
\end{tabular}


Table S3. Cartesian coordinates of the optimized geometry of I-ATT at B3LYP/6-31+G(d,p) [for the $\mathrm{C}, \mathrm{H}, \mathrm{S}$ ] and B3LYP/ LanL2DZ [for I] level of theory $(\mathrm{E}=-1499.14528485$, number of imaginary frequencies $=0$ ).

\begin{tabular}{rrrr}
\hline Atom & $\mathrm{X}$ & $\mathrm{Y}$ & $\mathrm{Z}$ \\
\hline $\mathrm{C}$ & -10.280774 & -5.034186 & -0.973233 \\
$\mathrm{C}$ & -9.003586 & -4.819769 & -1.422789 \\
$\mathrm{C}$ & -8.147440 & -3.865992 & -0.783037 \\
$\mathrm{C}$ & -8.658756 & -3.129121 & 0.352787 \\
$\mathrm{C}$ & -9.998485 & -3.384602 & 0.788888 \\
$\mathrm{C}$ & -10.785238 & -4.306657 & 0.147981 \\
$\mathrm{C}$ & -6.839852 & -3.625312 & -1.218840 \\
$\mathrm{C}$ & -7.831713 & -2.194010 & 0.986629 \\
$\mathrm{C}$ & -6.519593 & -1.949839 & 0.552221 \\
$\mathrm{C}$ & -6.005888 & -2.687651 & -0.585930 \\
$\mathrm{C}$ & -4.675838 & -2.444354 & -1.031294 \\
$\mathrm{H}$ & -4.296700 & -3.000435 & -1.884665 \\
$\mathrm{C}$ & -3.878749 & -1.517606 & -0.391322 \\
$\mathrm{C}$ & -5.679696 & -0.994898 & 1.201611 \\
$\mathrm{H}$ & -6.455958 & -4.179375 & -2.072512 \\
$\mathrm{H}$ & -10.918317 & -5.760674 & -1.468513 \\
$\mathrm{H}$ & -8.618783 & -5.372787 & -2.275813 \\
$\mathrm{H}$ & -10.381535 & -2.830569 & 1.642060 \\
$\mathrm{H}$ & -11.799595 & -4.489672 & 0.490214 \\
$\mathrm{H}$ & -8.216417 & -1.640358 & 1.840219 \\
$\mathrm{H}$ & -6.068025 & -0.444165 & 2.053751 \\
$\mathrm{C}$ & -4.404370 & -0.787479 & 0.744302 \\
$\mathrm{~S}$ & -3.222891 & 0.356211 & 1.425286 \\
$\mathrm{C}$ & -2.039618 & -0.131828 & 0.210501 \\
$\mathrm{C}$ & -2.524592 & -1.100309 & -0.648305 \\
$\mathrm{~S}$ & -1.320430 & -1.546638 & -1.826256 \\
$\mathrm{C}$ & -0.699973 & 0.274475 & -0.051702 \\
$\mathrm{H}$ & -0.189111 & -0.409042 & -1.125240 \\
\hline & -0.149357 & 1.018012 & 0.509940 \\
\hline & & -0.194167 & -1.932539 \\
\hline
\end{tabular}


Table S4. Cartesian coordinates of the optimized geometry of ATT cation computed at B3LYP/6$31+\mathrm{G}(\mathrm{d}, \mathrm{p})$ level of theory (charge $=+1$; spin multiplicity $=2, \mathrm{E}=-1488.13218973$, number of imaginary frequencies $=0$ ).

\begin{tabular}{rrrr}
\hline Atom & $\mathrm{X}$ & $\mathrm{Y}$ & $\mathrm{Z}$ \\
\hline $\mathrm{C}$ & -10.285987 & -5.039358 & -0.962918 \\
$\mathrm{C}$ & -9.001413 & -4.813809 & -1.427806 \\
$\mathrm{C}$ & -8.158392 & -3.869483 & -0.785216 \\
$\mathrm{C}$ & -8.659085 & -3.148657 & 0.358423 \\
$\mathrm{C}$ & -9.978036 & -3.403629 & 0.807977 \\
$\mathrm{C}$ & -10.775559 & -4.332483 & 0.157815 \\
$\mathrm{C}$ & -6.846199 & -3.616080 & -1.232779 \\
$\mathrm{C}$ & -7.820119 & -2.207961 & 0.998838 \\
$\mathrm{C}$ & -6.517888 & -1.956424 & 0.554533 \\
$\mathrm{C}$ & -6.011621 & -2.679590 & -0.594978 \\
$\mathrm{C}$ & -4.696729 & -2.433312 & -1.052901 \\
$\mathrm{H}$ & -4.322183 & -2.978142 & -1.914931 \\
$\mathrm{C}$ & -3.884091 & -1.498953 & -0.405583 \\
$\mathrm{C}$ & -5.680513 & -1.005971 & 1.206981 \\
$\mathrm{H}$ & -6.468498 & -4.159622 & -2.095157 \\
$\mathrm{H}$ & -10.922734 & -5.763245 & -1.460925 \\
$\mathrm{H}$ & -8.626808 & -5.358262 & -2.289635 \\
$\mathrm{H}$ & -10.359259 & -2.862808 & 1.669187 \\
$\mathrm{H}$ & -11.784433 & -4.519557 & 0.511091 \\
$\mathrm{H}$ & -8.201428 & -1.666404 & 1.860927 \\
$\mathrm{H}$ & -6.061167 & -0.464629 & 2.068364 \\
$\mathrm{C}$ & -4.403313 & -0.787425 & 0.737330 \\
$\mathrm{~S}$ & -3.233960 & 0.343825 & 1.414499 \\
$\mathrm{C}$ & -2.062442 & -0.110246 & 0.204973 \\
$\mathrm{C}$ & -2.549397 & -1.086917 & -0.678125 \\
$\mathrm{~S}$ & -1.350472 & -1.506739 & -1.862523 \\
$\mathrm{C}$ & -0.731936 & 0.301372 & -0.065975 \\
$\mathrm{C}$ & -0.230915 & -0.371069 & -1.151951 \\
$\mathrm{H}$ & -0.174443 & 1.040793 & 0.494666 \\
\hline & 0.753473 & -0.266065 & -1.589660 \\
\hline & & & \\
\hline
\end{tabular}


Table S5. Cartesian coordinates of the optimized geometry of I-ATT cation computed at B3LYP/6$31+\mathrm{G}(\mathrm{d}, \mathrm{p})[$ for the $\mathrm{C}, \mathrm{H}, \mathrm{S}$ ] and B3LYP/ LanL2DZ [for I] level of theory (charge $=+1$; spin multiplicity $=2, \mathrm{E}=-1498.90410466$, number of imaginary frequencies $=0$ ).

\begin{tabular}{rrrr}
\hline Atom & $\mathrm{X}$ & $\mathrm{Y}$ & $\mathrm{Z}$ \\
\hline $\mathrm{C}$ & -10.284242 & -5.029427 & -0.966908 \\
$\mathrm{C}$ & -8.995930 & -4.815314 & -1.423753 \\
$\mathrm{C}$ & -8.152312 & -3.868176 & -0.783842 \\
$\mathrm{C}$ & -8.658021 & -3.133040 & 0.348791 \\
$\mathrm{C}$ & -9.981883 & -3.377128 & 0.790283 \\
$\mathrm{C}$ & -10.778666 & -4.308136 & 0.143448 \\
$\mathrm{C}$ & -6.836440 & -3.626098 & -1.223326 \\
$\mathrm{C}$ & -7.819410 & -2.189938 & 0.986590 \\
$\mathrm{C}$ & -6.513681 & -1.949295 & 0.550823 \\
$\mathrm{C}$ & -6.002041 & -2.686709 & -0.587629 \\
$\mathrm{C}$ & -4.683193 & -2.451815 & -1.037385 \\
$\mathrm{H}$ & -4.304387 & -3.006995 & -1.890922 \\
$\mathrm{C}$ & -3.871130 & -1.514204 & -0.391938 \\
$\mathrm{C}$ & -5.675413 & -0.995406 & 1.200939 \\
$\mathrm{H}$ & -6.454208 & -4.179859 & -2.077149 \\
$\mathrm{H}$ & -10.921251 & -5.754969 & -1.462158 \\
$\mathrm{H}$ & -8.617040 & -5.370128 & -2.277070 \\
$\mathrm{H}$ & -10.367046 & -2.825735 & 1.642996 \\
$\mathrm{H}$ & -11.791222 & -4.486541 & 0.490710 \\
$\mathrm{H}$ & -8.205320 & -1.638171 & 1.840088 \\
$\mathrm{H}$ & -6.061038 & -0.444099 & 2.053702 \\
$\mathrm{C}$ & -4.395541 & -0.788083 & 0.740253 \\
$\mathrm{~S}$ & -3.223236 & 0.345497 & 1.415637 \\
$\mathrm{C}$ & -2.046299 & -0.128658 & 0.218467 \\
$\mathrm{C}$ & -2.534268 & -1.112478 & -0.657976 \\
$\mathrm{~S}$ & -1.328909 & -1.552169 & -1.830720 \\
$\mathrm{C}$ & -0.715408 & 0.276636 & -0.040449 \\
$\mathrm{C}$ & -0.201664 & -0.408334 & -1.119001 \\
\hline & -0.163415 & 1.019406 & 0.520512 \\
\hline
\end{tabular}




\section{References}

(1) Ogawa, Y.; Yamamoto, K.; Miura, C.; Tamura, S.; Saito, M.; Mamada, M.; Kumaki, D.; Tokito, S.; Katagiri, H. Asymmetric Alkylthienyl Thienoacenes Derived from Anthra[2,3-b]Thieno[2,3d]Thiophene for Solution-Processable Organic Semiconductors. ACS Applied Materials \& Interfaces 2017, 9 (11), 9902-9909.

(2) CrysAlisPro CCD, CrysAlisPro RED and ABSPACK in CrysAlisPro RED. Oxford Diffraction Ltd, Abingdon, England, 2006.

(3) Sheldrick, G. M. SHELXT - Integrated Space-Group and Crystal-Structure Determination. Acta Crystallogr., Sect. A: Found. Adv. 2015, 71, 3-8.

(4) Sheldrick, G. M. Crystal Structure Refinement with SHELXL. Acta Crystallogr., Sect. C: Cryst. Struct. Commun. 2015, 71, 3-8.

(5) Kabuto, C.; Akine, S.; Nemoto, T.; Kwon, E. Release of Software (Yadokari-XG 2009) for Crystal Structure Analyses. Nihon Kessho Gakkaishi 2010, 51, 218-224.

(6) Frisch, M. J.; Trucks, G. W.; Schlegel, H. B.; Scuseria, G. E.; Robb, M. A.; Cheeseman, J. R.; Scalmani, G.; Barone, V.; Mennucci, B.; Petersson, G. A.; Nakatsuji, H.;;et al. Gaussian 09, Revision D.01; Gaussian, Inc.: Wallingford, CT, 2009.

(7) ADF: Powerful DFT Code for Modeling Molecules; Scientific Computing and Modeling: Amsterdam, The Netherlands, http://www.scm.com/ADF/. 